\title{
Amplification of c-myc Locus is Independently Associated with the Deletions of Chromosome 8p in Breast Carcinoma
}

\author{
Nilanjana Bhattacharyaa, Neelanjana Chundera, Anup Royb, Niyaz Alama, \\ Susanta Roychoudhuryc and Chinmay Kumar Panda ${ }^{\mathrm{a}}$ * \\ ${ }^{a}$ Chittaranjan National Cancer Institute, 37, S.P. Mukherjee Road, Kolkata 700 026, \\ West Bengal, India \\ ${ }^{b}$ Department of Pathology, Medical College and Hospital, Kolkata 700 073, \\ West Bengal, India \\ 'Human Genetics and Genomics Division, Indian Institute of Chemical Biology, \\ 4, Raja S.C. Mullick Road, Kolkata 700 032, West Bengal, India
}

KEYWORDS Breast carcinoma; chromosome 8; c-myc locus; pal-1; mlvi-4

\begin{abstract}
Attempts have been made in this study is to find out the mechanism of c-myc gene activation in breast carcinoma $(\mathrm{CaBr})$ by analyzing alterations (rearrangement/amplification) in the $\sim 580 \mathrm{~Kb}$ surroundings of this gene. The alteration in the c-myc locus was correlated with the deletions in chromosome (chr.) $8 \mathrm{p}$ to find if there is any association between the two phenomenons. The c-myc locus alteration was analyzed by Southern hybridization using the pal-1/ c-myc/ mlvi-4 probes. Overall, amplification in the c-myc locus was seen in $26 \%$ of the samples with $22 \%$ in the pal-1 region, $19 \%$ in the c-myc gene and $7 \%$ in the mlvi-4 region. This indicates that the c-myc gene activation may occur due to the amplification in the pal-1 region located $550 \mathrm{~Kb} 5$ ' and mlvi-4 region located $20 \mathrm{~Kb}$ 3' of c-myc. About $42 \%$ of the samples showed loss of heterozygosity ( $\mathrm{LOH}$ ) in $\geq 40 \%$ of the microsatellite markers tested. Atleast $21 \%$ of the samples showed co-alterations in both arms of chr.8. No significant association was observed between the amplification in the c-myc locus and deletions in chr.8p. Thus the deletions in chr.8p and the amplification in the c-myc locus are independently associated with the development of $\mathrm{CaBr}$.
\end{abstract}

\section{INTRODUCTION}

$\mathrm{CaBr}$ is one of the most common cancers diagnosed in women worldwide and is a leading cause of cancer related deaths (Greenlee et al. 2000). In India, it is the second most common cancer among women, with 75,000 new cases being reported each year (Chopra et al. 2001). Etiological and epidemiological studies have identified both genetic and environmental factors like increasing age, the dose and duration of estrogen exposure, early menarche, late menopause, nulliparity etc to be responsible for the development of $\mathrm{CaBr}$ (Ang et al. 2001).

Molecular cytogenetic studies have identified deletions in the chr.8p and ampli-fications in the chr.8q24 to be one of the most common chromosomal abnormalities in the development of ductal carcinoma insitu (DCIS) from normal

*Address for Correpondence: Dr. C. K. Panda,

Department of Oncogene Regulation, Chittaranjan

National Cancer Institute, 37, S.P. Mukherjee Road,

Kolkata 700 026, West Bengal, India

Telephone: 91-33-2474-3922

Fax: 91-33-2475-7606

E-mail: ckpanda@vsnl.net epithelium (Ingvarsson 1999; Polyak 2002). But there are no data to suggest whether the alterations in chr.8 are independent events or there is any cooperativity among the alterations.

The amplification of the c-myc gene, located in chr.8q24.1, is found in $1-50 \%$ of the $\mathrm{CaBr}$ samples by Southern blot analysis (Deming et al. 2000). The variation in frequency of c-myc gene amplification among the investigators might be due to the differences in etiology, ethnicity and sample preparation. In other studies, it is evident that the c-myc gene can be activated by rearrangement/amplification/proviral integration in the long distance 5' and 3' region of this gene (Boxer LM et al. 2001). An HPV integration site is located at $550 \mathrm{~Kb}$ upstream of c-myc gene, named as pal-1 locus (Lazo et al. 1989; Ferber et al. 2003). Whereas, the homologous region of mlvi-4 (Moloney murine leukemia virus integration site4) is located about $20 \mathrm{~Kb} \mathrm{3'}$ ' of human c-myc (Tsichlis et al. 1990). In different human tumor cell lines for e.g. Colo320, HL60 etc, various sizes of the c-myc amplicon has been noted extending to at least $550 \mathrm{~Kb} 5$ ' of the c-myc gene reaching the pal- 1 locus and to about $300 \mathrm{~Kb}$ downstream reaching beyond the pvt-1 locus (Joos et al. 1992). 
But the importance of the pal-1 and mlvi-4 regions in $\mathrm{CaBr}$ has not yet been studied.

The allelotyping studies have identified about $41-74 \%$ deletions in the chr.8p region in $\mathrm{CaBr}$ (Kerangueven et al. 1995; Yaremko et al. 1995; Yaremko et al. 1996; Seitz et al. 1997; Wang et al. 1999; Yokota et al. 1999; Sigbjornsdottir et al. 2000). But there is ambiguity in localizing the common consensus deletion in these studies. We have identified 3 discrete areas of high $\mathrm{LOH}$ in chr.8p23.1-23.2, chr.8p23.1 and chr.8p 21.3- 22 regions in $\mathrm{CaBr}$ of Indian patients (Bhattacharya et al. 2004). But it is not still clear if there is any association with the alterations (amplification/ rearrangement) in the c-myc locus and deletions in chr.8p.

In the present study we would like to know if the c-myc gene activation occurs due to alterations (amplification/rearrangement) in the long distance region of the gene. Thus we have analyzed the alterations in the c-myc locus by Southern hybridization using the pal-1, c-myc, mlvi-4 probes in primary breast lesions of Indian patients. The alteration in the c-myc locus was then correlated with the deletions in chr.8p (Bhattacharya et al. 2004) to see if there is any association between the two phenomenons.

\section{MATERIALSAND METHODS}

Sample Collection and Clinical Data: Seventy primary breast lesions and their corresponding normal tissues or peripheral blood leukocytes (PBL) were obtained from 67 previously untreated patients with breast lesions from Chittaranjan National Cancer Institute, Kolkata. The samples were frozen immediately after collection and stored at $-80^{\circ} \mathrm{C}$ until further use. All the samples were collected after obtaining prior informed consent from the patients and clearance from the ethical committee of the hospital. The detailed patient history is presented in Table 1. The tumors were graded and staged according to UICC TNM classification (Harmer 1978). The mean age of the patients was 46.9 years with 65 female cases and 2 male cases. Among the patients, 59 were Hindus and 8 were Muslims. Among the 65 female patients, 4- cases were premenopausal cases and the rest were postmenopausal (Table 1).

Of the three bilateral cases used in our study, sample no. 2972 and 5287 were found to be synchronous carcinoma and operated on the same day. However, in case of 2972, both the left and right carcinoma were of stage III at the time of diagnosis but for case 5287, the right tumor was of stage III and the left carcinoma was of stage IV at the time of diagnosis. In the case of 3924 , the patient reported a stage III carcinoma in the right breast at the time of diagnosis while fibroademoma in the left breast with palpable lumps was detected about 25 years earlier. The cases of 2972 and 5287 did not have a family history of breast cancer while the case of 3924 had a positive family history.

Microdissection and DNA Isolation: The normal cells present as contaminant in the specimens were removed by microdissection procedure as described by Dasgupta et al (2002). Serial $10-20 \mu \mathrm{m}$ sections for microdissection and representative $5 \mu \mathrm{m}$ sections for histologic examination were cut out from the specimens using cryostat (Leica CM 1800, Germany). The $5 \mu \mathrm{m}$ sections were stained with hematoxyline and eosin for diagnosis as well as marking of the tumor rich regions. The normal cells were removed from the marked regions of the $10-20 \mu \mathrm{m}$ sections by microdissection procedure leaving the tumor rich regions. The sections containing $>60 \%$ tumor cells were taken for DNA extraction.

DNA was extracted from the microdissected tissue sections and their corresponding normal tissue or PBL by proteinase-K digestion followed by phenol: chloroform extraction (Sambrook et al. 1989). When the adjoining normal tissue of the lesion was contaminated with infiltrating tumor cells, then PBL was taken for normal DNA extraction.

Probe Information: The c-myc genomic probe is a $1.3 \mathrm{~Kb}$ Cla1- EcoR 1 fragment encompassing part of exon 3 of human c-myc gene (Lazo 1988). The mlvi-4 probe is a $1.4 \mathrm{~Kb}$ BamHI- Eco RI fragment (Tsichlis 1990). The pal-1 probe is a 1.4 Kb Hind III- Bgl II fragment (Lazo 1989). The CD3 $\gamma$ probe is a $0.8 \mathrm{~Kb}$ c-DNA probe (Krissansen 1986) located at chr.11q23.3 and used as control gene due to very low incidence of LOH/MA (Micro satellite size alteration) in this region as detected by allelotyping study using the flanking microsatellite markers (D11S1340 and D11S924) of the CD3 $\gamma$ gene (unpublished data). The CD3 $\gamma$ probe was used as an internal control in southern blot hybridization to standardize the amount of DNA load-ed and to asses the relative gene copy number of the c-myc / mlvi-4/ pal-1 gene. The probes were labeled with $\left[\alpha^{32} \mathrm{P}\right] \mathrm{dCTP}$ by random 
ALTERATIONS IN CHROMOSOME 8 IN BREAST CARCINOMA

Table 1: Clinicopathological and molecular features of the breast lesions

\begin{tabular}{|c|c|c|c|c|c|c|c|c|c|}
\hline Lesions & $\begin{array}{l}\text { Age / Sex / } \\
\text { Religion }\end{array}$ & $\begin{array}{l}\text { Clinical } \\
\text { Stage }\end{array}$ & $\begin{array}{l}\text { ymph node } \\
\text { status }\end{array}$ & $\begin{array}{l}\text { Tumor } \\
\text { Grade }\end{array}$ & $\begin{array}{c}\text { Menopausal Status } \\
\text { Pre / Post }\end{array}$ & $\begin{array}{l}\text { pal-1 } \\
\text { status }\end{array}$ & $\begin{array}{l}c-m y c \\
\text { status }\end{array}$ & $\begin{array}{l}\text { mlvi-4 } \\
\text { status }\end{array}$ & $\% \mathrm{LOH}$ \\
\hline 3970 & $40 / \mathrm{F} / \mathrm{H}$ & benign phyllodes & na & na & Pre & NA & NA & NA & ND \\
\hline 5393 & $25 / \mathrm{F} / \mathrm{H}$ & Fibroadenosis & na & na & Pre & NA & NA & NA & 6.7 \\
\hline 4616 & $42 / \mathrm{F} / \mathrm{H}$ & Fibroadenoma & na & na & Pre & NA & NA & NA & 0 \\
\hline 6038 & $64 / \mathrm{F} / \mathrm{H}$ & benign phyllodes & na & na & Post & ND & ND & ND & 0 \\
\hline 1770 & $40 / \mathrm{F} / \mathrm{H}$ & malignant phyllodes & na & na & Pre & ND & ND & ND & 0 \\
\hline 5892 & $35 / \mathrm{F} / \mathrm{H}$ & malignant phyllodes & na & na & Pre & ND & ND & ND & 0 \\
\hline 553 & $36 / \mathrm{F} / \mathrm{H}$ & I & - & ND & Pre & ND & ND & ND & 6.7 \\
\hline 1183 & $58 / \mathrm{F} / \mathrm{H}$ & II & + & iii & Post & ND & ND & ND & 26.7 \\
\hline 1186 & $42 / \mathrm{F} / \mathrm{H}$ & II & + & ii & Pre & ND & ND & ND & 53.3 \\
\hline 2434 & $55 / \mathrm{F} / \mathrm{H}$ & II & - & ii & Post & NA & NA & NA & 6.7 \\
\hline 2548 & $61 / \mathrm{F} / \mathrm{H}$ & II & + & $\mathrm{i}$ & Post & NA & NA & NA & 13.3 \\
\hline 2737 & $35 / \mathrm{F} / \mathrm{H}$ & II & + & ii & Pre & ND & ND & ND & 20 \\
\hline 3756 & $44 / \mathrm{F} / \mathrm{H}$ & II & - & ii & Post & NA & NA & NA & ND \\
\hline 3069 & $48 / \mathrm{F} / \mathrm{H}$ & II & + & $\mathrm{i}$ & Post & ND & ND & ND & 0 \\
\hline 4800 & $50 / \mathrm{F} / \mathrm{H}$ & II & + & ii & Post & ND & ND & ND & 6.7 \\
\hline 4832 & $59 / \mathrm{F} / \mathrm{H}$ & II & + & ii & Post & NA & NA & NA & 0 \\
\hline 5234 & $43 / \mathrm{F} / \mathrm{H}$ & II & + & ii & Pre & NA & $\mathrm{A}, 2 \uparrow$ & NA & ND \\
\hline 5364 & $38 / \mathrm{F} / \mathrm{H}$ & II & + & iii & Pre & NA & NA & NA & 53.3 \\
\hline 5432 & $52 / \mathrm{F} / \mathrm{H}$ & II & + & iii & Post & ND & ND & ND & 40 \\
\hline 6061 & $23 / \mathrm{F} / \mathrm{H}$ & II & - & ii & Pre & ND & ND & ND & 13.3 \\
\hline 76 & $45 / \mathrm{F} / \mathrm{H}$ & III & + & iii & Post & NA & NA & NA & 20 \\
\hline 107 & $38 / \mathrm{F} / \mathrm{H}$ & III & + & ii & Pre & ND & ND & ND & 6.7 \\
\hline 113 & $40 / \mathrm{F} / \mathrm{H}$ & III & - & iii & Pre & $\mathrm{A}, 2 \uparrow$ & $\mathrm{A}, 3 \uparrow$ & $\mathrm{A}, 5 \uparrow$ & 26.7 \\
\hline 170 & $55 / \mathrm{F} / \mathrm{H}$ & III & + & ND & Post & ND & ND & ND & 46.7 \\
\hline 324 & $35 / \mathrm{F} / \mathrm{H}$ & III & - & ii & Post & NA & NA & NA & 73.3 \\
\hline 366 & $25 / \mathrm{F} / \mathrm{H}$ & III & - & ND & Pre & ND & ND & ND & 13.3 \\
\hline 588 & $28 / \mathrm{F} / \mathrm{H}$ & III & - & iii & Pre & ND & ND & ND & 26.7 \\
\hline 1818 & $45 / \mathrm{F} / \mathrm{H}$ & III & + & iii & Pre & ND & ND & ND & 0 \\
\hline 1865 & $42 / \mathrm{F} / \mathrm{H}$ & III & - & iii & Pre & ND & ND & ND & 20 \\
\hline 2033 & $40 / \mathrm{F} / \mathrm{H}$ & III & + & iii & Pre & $\mathrm{A}, 2 \uparrow$ & NA & NA & 40 \\
\hline 2490 & $65 / \mathrm{F} / \mathrm{H}$ & III & - & iii & Post & ND & ND & ND & 13.3 \\
\hline 2766 & $52 / \mathrm{F} / \mathrm{H}$ & III & + & ii & Post & ND & ND & ND & 46.7 \\
\hline $2972 \mathrm{R}$ & $30 / \mathrm{F} / \mathrm{H}$ & III & + & ii & Pre & ND & ND & ND & 40 \\
\hline $2972 \mathrm{~L}$ & & III & + & ii & Pre & ND & ND & ND & 46.7 \\
\hline 3156 & $35 / \mathrm{F} / \mathrm{H}$ & III & + & ii & Pre & ND & ND & ND & 53.3 \\
\hline 3158 & $36 / \mathrm{F} / \mathrm{H}$ & III & - & iii & Pre & ND & ND & ND & 6.7 \\
\hline 3184 & $40 / \mathrm{F} / \mathrm{H}$ & III & - & iii & Pre & ND & ND & ND & 66.6 \\
\hline 3266 & $32 / \mathrm{F} / \mathrm{H}$ & III & + & ii & Pre & ND & ND & ND & 26.7 \\
\hline 3365 & $20 / \mathrm{F} / \mathrm{H}$ & III & - & $\mathrm{i}$ & Pre & ND & ND & ND & 6.7 \\
\hline 3025 & $62 / \mathrm{F} / \mathrm{H}$ & III & + & iii & Post & ND & ND & ND & 60 \\
\hline 3098 & $60 / \mathrm{F} / \mathrm{H}$ & III & + & ii & Post & ND & ND & ND & 40 \\
\hline 3379 & $46 / \mathrm{F} / \mathrm{H}$ & III & - & ND & Post & NA & NA & NA & ND \\
\hline 3615 & $48 / \mathrm{F} / \mathrm{H}$ & III & - & ND & Post & NA & NA & NA & ND \\
\hline $3924 \mathrm{R}$ & $52 / \mathrm{F} / \mathrm{H}$ & III & + & ii & Post & ND & ND & ND & 26.7 \\
\hline $3924 \mathrm{~L}$ & & Fibroadenoma & na & na & Post & ND & ND & ND & 33.3 \\
\hline 4010 & $52 / \mathrm{F} / \mathrm{H}$ & III & + & $\mathrm{i}$ & Post & ND & ND & ND & 60 \\
\hline 4124 & $35 / \mathrm{F} / \mathrm{H}$ & III & - & ii & Pre & ND & ND & ND & 46.7 \\
\hline 4131 & $63 / \mathrm{F} / \mathrm{H}$ & III & + & ii & Post & ND & ND & ND & 53.3 \\
\hline 4272 & $53 / \mathrm{F} / \mathrm{H}$ & III & + & ii & Post & NA & NA & NA & 53.3 \\
\hline 4370 & $60 / \mathrm{F} / \mathrm{H}$ & III & + & ii & Post & $\mathrm{A}, 5 \uparrow$ & NA & NA & 53.3 \\
\hline 4447 & $45 / \mathrm{F} / \mathrm{H}$ & III & + & ii & Post & $\mathrm{A}, 2 \uparrow$ & $\mathrm{A}, 2 \uparrow$ & NA & 6.7 \\
\hline 4482 & $29 / \mathrm{F} / \mathrm{H}$ & III & + & $\mathrm{i}$ & Pre & NA & NA & NA & 46.7 \\
\hline 4604 & $40 / \mathrm{F} / \mathrm{H}$ & III & + & iii & Pre & NA & NA & NA & 20 \\
\hline 4671 & $45 / \mathrm{F} / \mathrm{H}$ & III & + & iii & Pre & ND & ND & ND & 13.3 \\
\hline 4734 & $35 / \mathrm{F} / \mathrm{H}$ & III & + & $\mathrm{i}$ & Pre & ND & ND & ND & 26.7 \\
\hline 4953 & $25 / \mathrm{F} / \mathrm{H}$ & III & + & iii & Pre & NA & NA & NA & ND \\
\hline 5036 & $40 / \mathrm{F} / \mathrm{H}$ & III & - & ii & Pre & ND & ND & ND & 0 \\
\hline 5051 & $50 / \mathrm{F} / \mathrm{H}$ & III & + & ii & Post & $\mathrm{A}, 2 \uparrow$ & $\mathrm{A}, 2 \uparrow$ & NA & ND \\
\hline 5164 & $60 / \mathrm{M} / \mathrm{H}$ & III & + & ii & na & NA & NA & NA & 46.7 \\
\hline $5287 \mathrm{R}$ & $32 / \mathrm{F} / \mathrm{H}$ & III & - & ii & Pre & ND & ND & ND & 60 \\
\hline
\end{tabular}


Table 1 contd.....

\begin{tabular}{|c|c|c|c|c|c|c|c|c|c|}
\hline Lesions & $\begin{array}{l}\text { Age / Sex / } \\
\text { Religion }\end{array}$ & $\begin{array}{l}\text { Clinical } \\
\text { Stage }\end{array}$ & $\begin{array}{l}\text { Lymph node } \\
\text { status }\end{array}$ & $\begin{array}{l}\text { Tumor } \\
\text { Grade }\end{array}$ & $\begin{array}{c}\text { Menopausal Status } \\
\text { Pre / Post }\end{array}$ & $\begin{array}{l}\text { pal-1 } \\
\text { status }\end{array}$ & $\begin{array}{l}\text { c-myc } \\
\text { status }\end{array}$ & $\begin{array}{l}\text { mlvi-4 } \\
\text { status }\end{array}$ & $\% \mathrm{LOH}$ \\
\hline $5287 \mathrm{~L}$ & & IV & - & ii & Pre & ND & ND & ND & 60 \\
\hline 5337 & $52 / \mathrm{F} / \mathrm{H}$ & III & + & ii & Post & ND & ND & ND & 40 \\
\hline 5375 & $60 / \mathrm{F} / \mathrm{H}$ & III & - & ii & Post & NA & NA & NA & 40 \\
\hline 5451 & $45 / \mathrm{F} / \mathrm{H}$ & III & + & ii & Pre & ND & ND & ND & 66.6 \\
\hline 5580 & $30 / \mathrm{F} / \mathrm{H}$ & III & + & ii & Pre & $\mathrm{A}, 2 \uparrow$ & $\mathrm{A}, 4 \uparrow$ & $\mathrm{A}, 2 \uparrow$ & 26.7 \\
\hline 5585 & 38/F/H & III & - & $\mathrm{i}$ & Pre & NA & NA & NA & ND \\
\hline 5596 & $50 / \mathrm{M} / \mathrm{H}$ & III & + & ii & $\mathrm{na}$ & ND & ND & ND & 6.7 \\
\hline 6189 & $43 / \mathrm{F} / \mathrm{H}$ & III & + & $\mathrm{i}$ & Pre & ND & ND & ND & 53.3 \\
\hline 5557 & 38/F/M & IV & + & ii & Pre & NA & NA & NA & 13.3 \\
\hline 5700 & $36 / \mathrm{F} / \mathrm{H}$ & IV & + & iii & Pre & ND & ND & ND & 13.3 \\
\hline
\end{tabular}

Sex: F, Female; M, Male; Religion: H, hindu; M, muslim;

Menopausal status: Pre, premenopausal,Post, postmenopausal, na: not applicable

A: Amplification, NA: not amplified, ND: not done;

The upwards arrow and numbers in the gene status column indicate the increment in copy number of the gene.

Tumor Grade : i=Well Differentiated, ii=Moderately Differentiated, iii=Poorly Differentiated Squamous Cell

Carcinoma

priming method and used for analysis (Feinberg 1983).

Southern Blot Analysis: $10 \mu \mathrm{g}$ of genomic DNA from each sample was digested with Hind III for over night at $37^{\circ} \mathrm{C}$. The digested samples were then electrophoresed in $0.8 \%$ agarose gel for over night at $30 \mathrm{~V}$. The DNA in the gel was transferred to Genescreen nylon membrane (NEN, USA) by capillary transfer method. The prehybridization of the membranes were done in a solution containing $2 \mathrm{X}$ SSC, $1 \%$ SDS, $10 \%$ dextran sulphate, $50 \%$ deionized formamide and 5X Denhardht's solution for overnight at $42^{\circ} \mathrm{C}$. The purified labeled probe with specific activity $10^{8}-10^{9} \mathrm{CPM} / \mu \mathrm{g}$ of DNA was added to the prehybridisation solution and hybridized for overnight at $42^{\circ} \mathrm{C}$. After hybridization, the membranes were washed as follows: $10 \mathrm{~min}$ at room temperature in $2 \mathrm{X}$ SSC followed by washing at $42^{\circ} \mathrm{C}$ in $2 \mathrm{X} \mathrm{SSC}, 1 \% \mathrm{SDS}$ for $2 \mathrm{X} 20 \mathrm{~min}$ and finally in $0.2 \mathrm{X} \mathrm{SSC}, 1 \% \mathrm{SDS}$ at $42^{\circ} \mathrm{C}$ for $2 \mathrm{X} 20$ $\mathrm{min}$. The membranes were then exposed to Kodak $\mathrm{X}-\mathrm{Omat}$ film at $-80^{\circ} \mathrm{C}$ for $7-8$ days with intensifying screen. The intensity of the hybridized bands on the autoradiographs was determined by densitometric scanner (Shimadzu CS-1900). The intensity of c-myc / mlvi-4/ pal-1 band in each sample was normalized with respect to the intensity of the CD3 $\gamma$ band of the corresponding sample. The copy number of c-myc / mlvi-4 / pal1 loci in the breast lesions was calculated from the ratio of the normalized intensities of the bands in breast lesions and normal sample. The c-myc / mlvi-4 / pal-1 locus was considered to be amplified when the ratio was $\geq 2$ (Deming et al. 2000).
Allelotyping Study: We used 15 highly polymorphic microsatellite markers located on chr.8p to study the allelic alterations (Bhattacharya et al, 2004). The detailed experimental procedure used for the allelotyping analysis is given in our previous study (Bhattacharya et al. 2004). The samples showing alteration in $\geq 40 \%$ of the microsatellite markers tested can be considered as highly unstable (Boland 1998).

Statistical Analysis of the Clinical Data: To determine the association of the different clinicopathological features (age of onset, menopausal grade, tumor grade and lymph node status) of the breast lesions with c-myc locus alterations as well as the inter relationship between the alterations of chr.8, the Chi- square analysis was performed. A probability value of $\mathrm{P} \leq 0.05$ was considered as statistically significant.

\section{RESULTS}

c-myc Locus Alteration in the Breast Lesions: The c-myc locus was found to be amplified in $26 \%(7 / 27)$ cases for at least one of the three probes analyzed (Table 1, Fig. 1). The c-myc gene, pal-1 region and mlvi-4 regions were amplified in about $19 \%(5 / 27), 22 \%(6 / 27)$ and $7 \%(2 / 27)$ samples respectively. The co-amplification of the pal-1 - c-myc - mlvi-4 locus was seen in 2 cases (sample \# 113 and 5580). The c-myc was seen to be co-amplified with pal-1 in 2 cases (samples \# 4447 and 5051). No significant clinicopathological association was found between the amplification in c-myc locus with the different clinical parameters like age of onset, menopausal status, tumor grade and lymph node involvment (Table 2). 


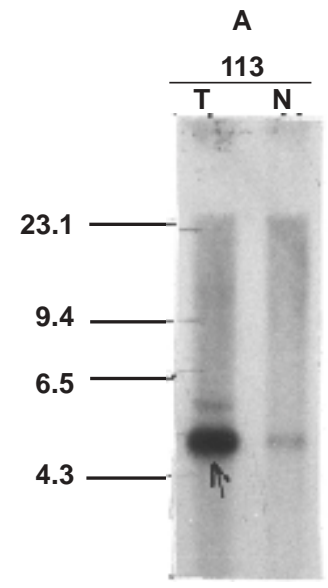

Probes: $\quad$ mlvi-4

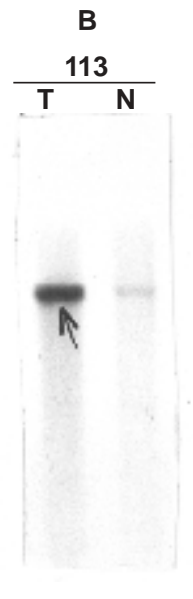

c-myc

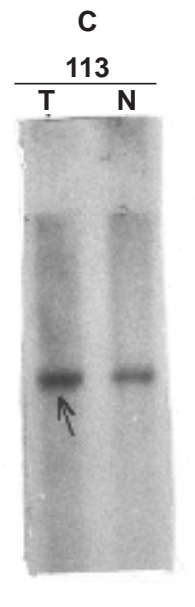

pal-1

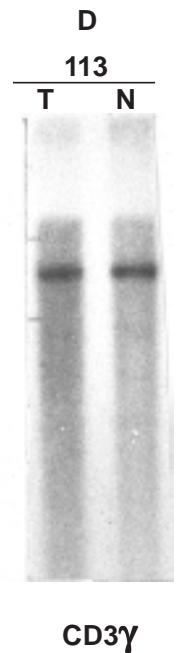

Fig. 1. Representative photograph showing amplification of the c-myc locus.

Panel A: Hybridization of the samples with the mlvi-4 probe

Panel B: Hybridization of the samples with the c-myc probe.

Panel C: Hybridization of the samples with the pal-1 probe.

Panel D: Hybridization of the samples with the CD3ã probe.

$\mathbf{T}$ : DNA of the primary tumor cells after microdissection; $\mathbf{N}$ : corresponding PBL.

$\uparrow$ indicates rearrangement. Lambda DNA digested with Hind III was used as marker shown on the left side of Panel A.

Inter-relationship of the Amplification in the c-myc Locus with the Deletions in chr.8p: In the deletion mapping of chr.8p using 15 microsatellite markers, about $42 \%(26 / 62)$ of the samples showed deletions in $\geq 40 \%$ of the markers (Table 1). In chr.8p, we have detected 3 discrete highly deleted areas in the chromosomal 8p23.1-

Table 2: Clinicopathological correlation of amplification in the c-myc locus with the breast lesions.

\begin{tabular}{|c|c|c|c|}
\hline \multirow[t]{2}{*}{$\begin{array}{l}\text { Clinicopathological } \\
\text { parameters }\end{array}$} & \multicolumn{2}{|c|}{$\begin{array}{l}\text { Amplification of } \\
\text { the c-myc locus }\end{array}$} & \multirow[t]{2}{*}{$\begin{array}{c}P- \\
\text { value }\end{array}$} \\
\hline & Locus + & Locus - & \\
\hline \multicolumn{4}{|l|}{ Age at Diagnosis } \\
\hline$\leq 40$ & 5 & 14 & \multirow[t]{2}{*}{$\leq 1$} \\
\hline$\geq 40$ & 2 & 6 & \\
\hline \multicolumn{4}{|l|}{ Menopausal Status } \\
\hline Premenopausal & 4 & 9 & \multirow[t]{2}{*}{$\leq 0.2$} \\
\hline Postmenopausal & 3 & 1 & \\
\hline \multicolumn{4}{|l|}{ Lymph node Status* } \\
\hline Positive & 6 & 10 & \multirow[t]{2}{*}{$\leq 1$} \\
\hline Negative & 1 & 7 & \\
\hline \multicolumn{4}{|l|}{ Tumor Grade* } \\
\hline Grade I & 0 & 4 & \multirow{3}{*}{$\leq 1$} \\
\hline Grade II & 5 & 7 & \\
\hline Grade III & 2 & 4 & \\
\hline
\end{tabular}

* For breast carcinoma samples

23.2, 8p23.1, 8p21.3-22 regions (Bhattacharya et al, 2004). About 21\% (4/19) samples showed ampli-fication in the c-myc locus and $\mathrm{LOH}$ for at least one of the markers (Table 1). No significant association was found between the samples showing deletion in $\geq 40 \%$ of the microsatellite marker in chr.8p and amplification in the c-myc locus (Table 3).

Table 3: Inter relationship of the deletions in chr. 8p with amplification in c-myclocus

\begin{tabular}{|c|c|c|c|}
\hline \multirow{2}{*}{$\begin{array}{l}\text { Samples showing } \\
\text { LOH at chr. } 8 p\end{array}$} & \multicolumn{2}{|c|}{ c-mус locus } & \multirow{2}{*}{$\begin{array}{c}P- \\
\text { value }\end{array}$} \\
\hline & $\begin{array}{l}\text { amplifi- } \\
\text { cation + }\end{array}$ & $\begin{array}{l}\text { amplifi- } \\
\text { cation - }\end{array}$ & \\
\hline$\leq 40 \%$ & 2 & 6 & $\leq 1$ \\
\hline$\geq 40 \%$ & 2 & 9 & \\
\hline
\end{tabular}

Attempts have been made in this study to investigate whether the c-myc gene activation occurs due to distant alteration in the 5' and/or 3 ' region of this gene in primary $\mathrm{CaBr}$. Also, whether the alterations of the c-myc locus have any association with the deletions in chr.8p has also been studied. It is evident that the pal-1 region, c-myc gene and the mlvi-4 region are amplified in some breast lesions. This indicates that in $\mathrm{CaBr}$, c-myc can be activated by distant 
alterations of this gene like that have been seen in some lyphomas, colon carcinoma etc (Joos et al. 1992; Boxer et al. 2001). The amplification seen in the proviral insertion site either in the 5 , or 3' region of c-myc gene i.e. pal-1 and mlvi-4 region may activate the c-myc gene by cis-acting mechanism operating over long distances of genomic DNA. In Hela cell, HPV18 integration at the pal-1 site is found to enhance the c-myc expression (Lazo et al. 1989). On the other hand the mlvi-4 region is altered in some human neoplasias (Tsichlis et al. 1990). Like Colo320 and HL60 cell lines, the co-amplification seen in the pal-1-cmyc-mlvi-4 region in some $\mathrm{CaBr}$ samples indicates that similar type of c-myc activation occurs in the different tumor types. But unlike us, no one has seen the amplification in the pal-1 region $(22 \%)$ and mlvi-4 region $(7 \%)$ in $\mathrm{CaBr}$. However, similar to our result of c-myc gene amplification (19\%), other investigators (Cline et al. 1987; Varley et al. 1987; Adnane et al. 1989; Garcia et al. 1989; Tavassoli et al. 1989; Brouillet et al. 1990; Berns et al. 1992; Roux-Dosseto et al. 1992; Beiche et al, 1994) have observed $15-25 \%$ amplification of this gene in their studies. On the other hand, another group of investigators (Escot et al. 1986; Bonilla et al. 1988; Munzel et al.1991; Kreipe et al. 1993; Scorilas et al. 1993; Champeme et al. 1994; Harada et al. 1994; Scorilas et al. 1995) have observed $27-50 \%$ c-myc gene amplification in their studies. This might be due to the differences in ethnicity, etiology and sample preparation.

The high incidence of deletion of chr.8p in $\geq$ $40 \%$ of the markers indicates that the deletion in this region is associated with the development of $\mathrm{CaBr}$. In our previous study we have detected 3 discrete areas of high $\mathrm{LOH}$ in the chr.8p i.e. chr.8p23.1-23.2, chr.8p23.1 and chr.8p 21.3-22 regions associated with $\mathrm{CaBr}$ (Bhattacharya et al. 2004). But we did not find any association between the c-myc locus amplification and deletions in chr.8p. This indicates that the deletion and the c-myc locus amplification are two independent phenomenon associated with the development of $\mathrm{CaBr}$. Though these two phenomenons are independent, yet they may impose selective pressure for growth advantage of the tumor.

\section{ACKNOWLEDGEMENT}

We are grateful to the Director, Chittaranjan National Cancer Institute (CNCI), Kolkata for active encouragement during this work.

\section{REFERENCES}

Adnane J, Gaudray P, Simon MP, Simony -Lafontaine J, Jeanteur P, Theillet C 1989. Proto-oncogene amplification and human breast tumor phenotype. Oncogene, 4: 1389-1395.

Ang P. Garber J.E 2001. Genetic susceptibility of breast cancer- risk assessment and counseling. Semin Oncol, 28: 419-433.

Berns EMJJ, Klijn JGM, van Puten WLJ, van Staveren IL, Portengen H, Fockens JA 1992. C-myc amplification is a better prognostic factor than HER/neu amplification in primary breast cancer. Cancer Res, 52: 1101-1113.

Bieche I, Champeme MH, Linderau R 1994. A tumor suppressor gene on chromosome 1p32-pter controls the amplification of MYC family genes in breast cancer. Cancer Res, 54: 4274 - 4276.

Bhattacharya N, Chunder N, Basu D, Roy A, Mandal R, Majumder J, Roychowdhury S, Panda CK 2004. Three discrete areas within the chromosomal 8p21.3-23 region are associated with the development of breast carcinoma of Indian patients. Exp Mol Pathol, 76: 264-271.

Bonilla M, Ramirez M, Lopez-Cueto J, Gariglio P 1988. Invivo amplification and rearrangement of c-myc oncogene in human breast tumors. J Natl Cancer Inst, 80: 665-671.

Boxer LM, Dang CV 2001. Translocation involving cmyc and c-myc function. Oncogene, 20: 55955610.

Brouillet JP, Theillt C, Maudelonde T, Defrenne A, Simony -Lafontaine J, Sertour J, Pujol H, Jeantuer P, Rochefort H 1990. Cathepsin D assay in primary breast cancer and lymph nodes: Relationship with c-myc, c-erbB-2, and int-2 oncogene amplification and node invasiveness. Eur J Cancer, 26: 437-441

Champeme MH, Bieche I, Hacen K, Linderau R 1994. Oncogene amplification per se: An independent prognostic factor in human breast cancer. Mol Carcinog, 11: 189-191.

Chopra R 2001. The Indian scene. J Clin Oncol, 19 (18 Suppl): 106S-111S

Cline MJ, Battifora H, Yokota J 1987. Proto-oncogene abnormalities in human breast cancer: correlations with anatomic features and clinical course of disease. $J$ Clin Oncol, 5: 999-1006.

Dasgupta S, Mukherjee N, Roy S, Roy A, Sengupta A, Roychoudhury S, et al 2002. Mapping of the candidate tumor suppressor genes' loci on human chromosome 3 in head and neck squamous cell carcinoma of Indian Patient Population. Oral Oncol, 38: 6-15.

Deming SL, Nass SJ, Dickson RB, Trock BJ 2000. Cmyc amplification in beast cancer: a meta-analysis of its occurrence and prognostic relevance. $\mathrm{Br} J$ Cancer, 83: 1688-1695.

Escot C, Theillet C, Linderau R. Spyratos F, Champeme MH, Gest J, Callahan R 1986. Genetic alteration of the c-myc proto-oncogene (MYC) in human primary breast carcinomas. Proc Natl Acad Sci USA, 83: 4834-4839.

Feinberg AP, Vogelstein B 1983. A technique for radiolabeling DNA restriction endonuclease 
fragments to high specific activity. Anal Biochem, 132: $6-13$.

Ferber MJ, Thorland EC, Brink AA, Rapp AK, Phillips LA, McGovern R, Gostout BS, Cheung TH, Chung TK, Fu WY, Smith DI 2003. Preferential integration of human papillomavirus type 18 near the c-myc locus in cervical carcinoma. Oncogene, 22: 72337242 .

Garcia I, Deitrich PY, Aapro M, Vauthier G, Vadas L, Engel F 1989. Genetic alterations of c-myc, c-erbB2 and c-Ha-ras proto-oncogenes and clinical associations in human breast carcinomas. Cancer Res, 49: 6675-6679.

Greenlee, RT, Murray T, Bolden S, Wingo PA 2000. Cancer Statistics, 2000. CA Cancer J Clin, 50: 733.

Harada Y, Katagiri T, Ito I, Akiyama F, Sakamoto G, Kasumi F, Nakamura Y, Emi M 1994. Genetic studies of 457 breast cancers, clinicopathologic parameters compared with genetic alterations. Cancer, 74: 2281-2286.

Ingvarsson S 1999. Molecular genetics of breast cancer progression. Sem Cancer Biol, 9: 277-288.

Joos S, Haluska FG, Martin HF, Henglein B, Hameister H, Croce CM, Bornkamm GW 1992.

Mapping chromosomal breakpoint of Burkitt,s $\mathrm{t}(8 ; 14)$ translocations far upstream of c-myc. Cancer Res, 52: $6547-6552$.

Kerangueven F, Essioux L, Dib A, Noguchi T, Allione F, Geneix J, Longy M, Lidereau R, Eisinger F, Pebusque M.J, Jacquemier J, Bonaiti-Pellie C, Sobol H, Birnbaum D 1995. Loss of heterozygosity and linkage analysis in breast carcinoma: Indication for a putative third susceptibility gene on the short arm of chromosome 8. Oncogene, 10: 1023-1026.

Kreipe H, Fischer L, Feloner J, Heidorn K, Mettler L, Parwaresch R 1993. Amplification of c-myc but not c-erbB2 is associated with high proliferative capacity in breast cancer. Cancer Res, 53: 19561961.

Krissansen GW, Owen MJ, Verbi W, Crumpton MJ 1986. Primary structure of the T3 ã subunit of the T3/T cell antigen receptor complex deduced from cDNA sequences: evolution of the T3 ã and ä subunits. EMBO J, 5: 1799-1808.

Lazo PA, DiPaolo JA, Popescu NC 1989. Amplification of the integrated viral transforming genes of human papillomavirus 18 and its 5 '-flanking cellular sequence located near the myc protooncogene in HeLa cells. Cancer Res, 49: 4305-4310.

Munzel P, Marx D, Kochei H, Schauer A, Bock KW 1991. Genomic alterations of the c-myc protooncogene in relation to the overexpression of cerbB-2 and KI-67 in human breast and cervix carcinomas. J Cancer Res Clin Oncol, 117: 603607.

Polyak KS 2002. Molecular alterations in ductal carcinoma in situ of the breast. Curr Opin Oncol, 14: $92-96$.

Roux-Dosseto M, Romain S, Dussault N, Desideri C, Piana L, Bonnier P, Tubiana N, Martin PM 1992. $\mathrm{C}$-myc gene amplification in selected node-negative breast cancer patients correlates with high rate of early relapse. Eur J Cancer, 28A: 1600-1604.
Sambrook J, Fritsch EF, Maniatis T 1989. Molecular Cloning: A Laboratory Manual. $2^{\text {nd }}$ Ed. New York: Cold Spring Harbor Laboratory

Scorilas A, Yotis J, Gouriotis D, Keramopoulous A, Ampela K, Trangas T, Talieri M 1993. Cathepsin $\mathrm{D}$ and c-erb-B2 have an additive prognostic value for breast cancer patients. Anticancer Res, 13: 18951900 .

Scorilas A, Yotis J, Stravolemos K, Gouriotis D, Keramopoulous A, Ampela K, Talieri M Trangas T, 1995. c-erb-B2 overexpression may be used as an independent prognostic factor for breast cancer patients. Anticancer Res, 15: 1543-1548.

Seitz S, Rohde K, Bender E, Nothnagel A, Pidde H, Ullrich OM, El-Zehairy A, Haensch W, Jandrig B, Kolble K, Schlag PM, Scherneck S 1997. Deletion mapping and linkage analysis provide strong indication for the involvement of the human chromosome region 8 p12-22 in breast carcinogenesis. Br J Cancer, 76: 983-991.

Sigbjornsdottir BI, Ragnarsson G, Angnarsson BA, Huiping C, Barakardottir R.B, Egilsson V, Ingvarsson S 2000. Chromosome $8 \mathrm{p}$ alterations in sporadic and BRCA2 999del5 linked breast cancer. $J$ Med Genet, 37: 342-347.

Tavassoli M, Quirke P, Farzaneh F, Lock NJ, Mayne LV, Kirkham N 1989. C-erbB-2/cerbA co-amplification indicative of lymph node metastatis, and c-myc amplification of high tumor grade in human breast carcinoma. Br J Cancer, 60: 505-510.

Tsichlis PN, Lee JS, Bear SE, Lazo PA, Patriotis C, Gustafson E, Shinton S, Jenkins NA, Copeland NG, Huebner K, Croce C, Levan G, Hanson C 1990. Activation of multiple genes by provirus integration in the Mlvi-4 locus in T-cell lymphomas induced by Moloney murine leukemia virus. J Virol, 64: 2236-44.

Varley JM, Swallow JE, Brammer WJ, Whittaker JL, Walker RA 1987. Alteration to either c-erbB-2 (neu) or c-myc proto-oncogenes in breast carcinomas correlate with poor short term prognosis. Oncogene, 1: 423-430.

Wang JC, Radford DM, Holt MS, Helms C, Goate A, Brandt W, Parik M, Phillips NJ, DeSchryver KS, Schuh ME, Fair KL, Ritter JH, Marshall P, DonisKeller H 1999. Sequence-ready contig for the 1.4cM ductal carcinoma in situ loss of heterozygosity region on chromosome 8p22-p23. Genomics, 60: $1-11$

Yaremko ML, Recant WM, Westbrook CA 1995. Loss of heterozygosity from the short arm of chromosome 8 is an early event in breast cancers. Gene Chromosome Cancer, 13: 186-191.

Yaremko ML, Kutza C, Lyzak J, Mick R, Recant WM, Westbrook CA 1996. Loss of heterozygosity from the short arm of chromosome 8 is associated with invasive behavior in breast cancer. Gene Chromosome Cancer, 16: 189-195.

Yokota T, Yoshimoto M, Akiyama F, Sakamoto G, Kasumi F, Nakamura Y, Emi M 1999. Localization of a tumor suppressor gene associated with the progression of human breast carcinoma within a 1cM interval of 8p22-p23.1. Cancer, 85: 447-452. 